\title{
The alterations of cytokeratin and vimentin protein expressions in primary esophageal spindle cell carcinoma
}

\author{
Xin Min Li ${ }^{1}$, Xin Song ${ }^{1}$, Xue Ke Zhao ${ }^{1}$, Shou Jia Hu', Rang Cheng ${ }^{1}$, Shuang Lv ${ }^{1,2}$, Dan Feng Du ${ }^{1,3}$, \\ Xiang Yang Zhang ${ }^{1}$, Jian Liang Lu, ${ }^{1,2}$, Jian Wei Ku ${ }^{1,4}$, Dong Yun Zhang ${ }^{1,5}$, Yao Zhang ${ }^{6}$, Zong Min Fan \\ and Li Dong Wang ${ }^{1 *}$ (i)
}

\begin{abstract}
Background: The accumulated evidence has indicated the diagnostic role of cytokeratin (CK) and vimentin protein immunoassay in primary esophageal spindle cell carcinoma (PESC), which is a rare malignant tumor with epithelial and spindle components. However, it is largely unknown for the expression of CK and vimentin in pathological changes and prognosis of PESC.

Methods: Eighty-two PESC patients were identified from the esophageal and gastric cardia cancer database established by Henan Key Laboratory for Esophageal Cancer Research of Zhengzhou University. We retrospectively evaluated CK and vimentin protein expressions in PESC. Clinicopathological features were examined by means of univariate and multivariate survival analyses. Furthermore, the co-expression value of cytokeratin and vimentin was analyzed by receiver operating characteristic (ROC) curve.

Results: The positive pan-cytokeratins AE1/AE3 (AE1/AE3 for short) staining was chiefly observed in cytoplasm of epithelial component tumor cells, with a positive detection rate of 85.4\% (70/82). Interestingly, 19 cases showed AE1/ AE3 positive staining both in epithelial and spindle components (23.2\%). However, AE1/AE3 expression was not observed with any significant association with age, gender, tumor location, gross appearance, lymph node metastasis and TNM stage. Furthermore, AE1/AE3 protein expression does not show any effect on survival. Similar results were observed for vimentin immunoassay. However, in comparison with a single protein, the predictive power of AE1/AE3 and vimentin proteins signature was increased apparently than with single signature $[0.75(95 \% \mathrm{Cl}=0.68-0.82)$ with single protein v.s. $0.89(95 \% \mathrm{Cl}=0.85-0.94)$ with AE1/AE3 and vimentin proteins]. The 1-, 3-, 5- and 7-year survival rates for PESC patients in this study were $79.3 \%, 46.3 \%, 28.0 \%$ and $15.9 \%$, respectively. Multivariate analysis demonstrated age and TNM stage were independent prognostic factors for overall survival $(P=0.036$ and 0.003 , respectively). It is noteworthy that only $17.1 \%$ patients had a PESC accurate diagnosis by biopsy pathology before surgery (14/82). $72.4 \%$ PESC patients with biopsy pathology before surgery had been diagnosed as squamous cell carcinoma.

Conclusion: The present study demonstrates that cytokeratin and vimentin protein immunoassay is a useful biomarker for PESC accurate diagnosis, but not prognosis. The co-expression of cytokeratin and vimentin in both epithelial and spindle components suggest the possibility of single clone origination for PESC.
\end{abstract}

Keywords: Esophagus, Spindle cell carcinoma, Immunohistochemical staining, Cytokeratin, Vimentin

\footnotetext{
* Correspondence: Idwang2007@126.com

${ }^{1}$ Henan Key Laboratory for Esophageal Cancer Research of the First Affiliated

Hospital, Zhengzhou University, 40 Daxue Road, Zhengzhou, Henan 450052,

People's Republic of China

Full list of author information is available at the end of the article
} 
Table 1 Clinical characteristics of 82 PESC patients $n(\%)$

\begin{tabular}{|c|c|}
\hline & No. of case of examination (\%) \\
\hline \multicolumn{2}{|l|}{ Age } \\
\hline$<60$ years & $26(31.7)$ \\
\hline$\geq 60$ years & $56(68.3)$ \\
\hline \multicolumn{2}{|l|}{ Gender } \\
\hline Male & $57(69.5)$ \\
\hline Female & $25(30.5)$ \\
\hline \multicolumn{2}{|l|}{ Family history } \\
\hline Positive & $18(22.0)$ \\
\hline Negative & $64(78.0)$ \\
\hline \multicolumn{2}{|l|}{ Smoking } \\
\hline Yes & $41(50.0)$ \\
\hline No & $41(50.0)$ \\
\hline \multicolumn{2}{|l|}{ Alcohol } \\
\hline Yes & $36(43.9)$ \\
\hline No & $46(56.1)$ \\
\hline \multicolumn{2}{|c|}{ Tumor location } \\
\hline Upper $^{\mathrm{a}}$ & $3(3.7)$ \\
\hline Middle & $54(65.9)$ \\
\hline Lower & $25(30.4)$ \\
\hline \multicolumn{2}{|c|}{ Gross appearance } \\
\hline Polypoid & $69(84.1)$ \\
\hline Ulcerative & $8(9.8)$ \\
\hline Infiltrating & $5(6.1)$ \\
\hline \multicolumn{2}{|c|}{ Lymph node metastasis } \\
\hline Yes & $23(28.0)$ \\
\hline No & $59(72.0)$ \\
\hline \multicolumn{2}{|l|}{ TNM stage } \\
\hline । & $29(35.4)$ \\
\hline$\|$ & $37(45.1)$ \\
\hline III & $16(19.5)$ \\
\hline IV & $0(0.0)$ \\
\hline
\end{tabular}

${ }^{a}$ There was one patient whose tumor location was in cervical segment

\section{Background}

The primary esophageal spindle cell carcinoma (PESC), which has also been referred to as carcinosarcoma, sarcomatoid carcinoma, pseudosarcoma, pseudosarcomatous carcinoma, or polypoid carcinoma in literature, has been classified as a subtype of esophageal squamous cell carcinoma by WHO in 2010 [1]. Histopathologically, PESC is characterized by mixed two components, i.e., epithelial and spindle. Although the histogenesis of these two different components remains largely unknown, the accumulated evidence from many case reports has indicated the differential role of cytokeratin (CK) and vimentin protein immunoassay in PESC diagnosis [2-5]. However, it has not been well characterized in terms of

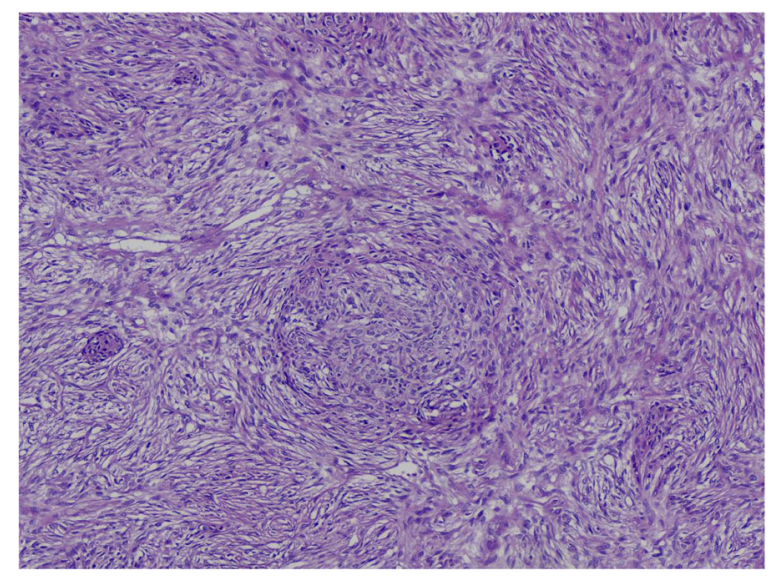

Fig. 1 Histological examination (100x) revealed two tumor components

immunohistochemical features for $\mathrm{CK}$ and vimentin in PESC accurate diagnosis and prognosis prediction.

In the present study, we retrospectively analyzed the $\mathrm{CK}$ and vimentin immunoreactivity and their possible roles in accurate diagnosis and prognosis on 82 cases with PSEC, which were retrieved from our esophageal cancer database from 1973 to 2015.

\section{Methods \\ Patients}

The two hundreds and eighty-six PESC patients were identified from the esophageal and gastric cardia cancer database (with a total of 500,000 patients) established by Henan Key Laboratory for Esophageal Cancer Research, the First Affiliated Hospital of Zhengzhou University from 1973 to 2015 [6]. Based on the criteria of more than 5 year follow-up after surgical treatment and

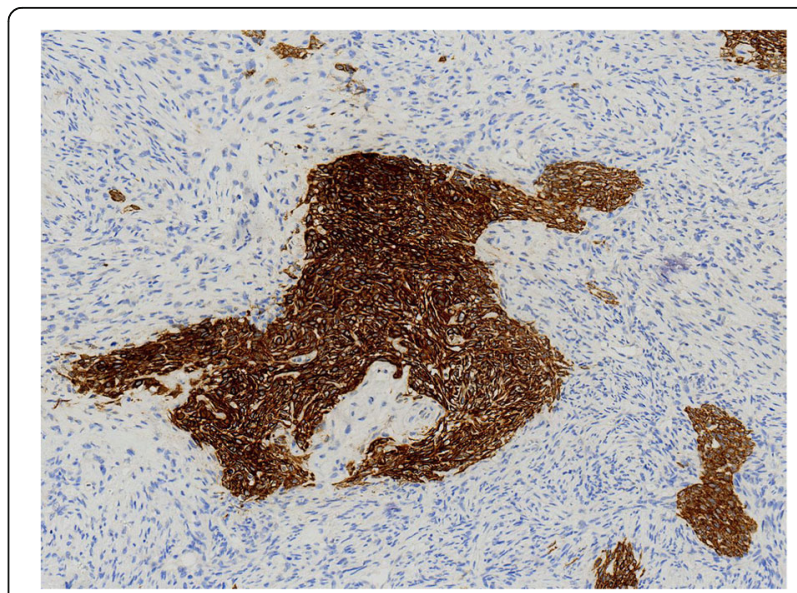

Fig. 2 The protein expressions of AE1/AE3 in PESC tissues by immunohistochemistry $(100 x)$. The positive immunostaining of AE1/ AE3 was localized in cell cytoplasm of epithelial component 
Table 2 The expression rate of AE1/AE3 protein in PESC

\begin{tabular}{|c|c|c|c|c|c|}
\hline & \multirow[t]{2}{*}{ Number } & \multicolumn{2}{|c|}{$\begin{array}{l}\text { Expression rate of } \\
\text { AE1/AE3 protein (\%) }\end{array}$} & \multirow[t]{2}{*}{$x^{2}$} & \multirow[t]{2}{*}{$P$} \\
\hline & & Positive $(n=70)$ & Negative $(n=12)$ & & \\
\hline \multicolumn{6}{|l|}{ Age } \\
\hline$<60$ years & 26 & $19(73.1)$ & $7(26.9)$ & \multirow[t]{2}{*}{3.28} & \multirow[t]{2}{*}{0.070} \\
\hline$\geq 60$ years & 56 & $51(91.1)$ & $5(8.9)$ & & \\
\hline \multicolumn{6}{|l|}{ Gender } \\
\hline Male & 57 & $48(84.2)$ & $9(15.8)$ & \multirow[t]{2}{*}{0.01} & \multirow[t]{2}{*}{0.914} \\
\hline Female & 25 & $22(88.0)$ & $3(12.0)$ & & \\
\hline \multicolumn{6}{|l|}{ Family history } \\
\hline Positive & 18 & $16(88.9)$ & $2(11.1)$ & \multirow[t]{2}{*}{0.01} & \multirow[t]{2}{*}{0.919} \\
\hline Negative & 64 & $54(84.3)$ & $10(15.7)$ & & \\
\hline \multicolumn{6}{|l|}{ Smoking } \\
\hline Yes & 41 & 34 (82.9) & $7(17.1)$ & \multirow[t]{2}{*}{0.10} & \multirow[t]{2}{*}{0.755} \\
\hline No & 41 & $36(87.8)$ & $5(12.2)$ & & \\
\hline \multicolumn{6}{|l|}{ Alcohol } \\
\hline Yes & 36 & $30(83.3)$ & $6(16.7)$ & \multirow[t]{2}{*}{0.21} & \multirow[t]{2}{*}{0.654} \\
\hline No & 46 & $40(87.0)$ & $6(13.0)$ & & \\
\hline \multicolumn{6}{|c|}{ Tumor location } \\
\hline Upper & 3 & $2(66.7)$ & $1(33.3)$ & \multirow[t]{3}{*}{1.48} & \multirow[t]{3}{*}{0.580} \\
\hline Middle & 54 & $46(85.2)$ & $8(14.8)$ & & \\
\hline Lower & 25 & $22(88.0)$ & $3(12.0)$ & & \\
\hline \multicolumn{6}{|c|}{ Gross appearance } \\
\hline Polypoid & 69 & $59(85.5)$ & $10(14.5)$ & \multirow[t]{3}{*}{1.30} & \multirow[t]{3}{*}{0.660} \\
\hline Ulcerative & 8 & $6(75.0)$ & $2(25.0)$ & & \\
\hline Infiltrating & 5 & $5(100.0)$ & $0(0.0)$ & & \\
\hline \multicolumn{6}{|c|}{ Lymph node metastasis } \\
\hline Yes & 23 & $21(91.3)$ & $2(8.7)$ & \multirow[t]{2}{*}{0.36} & \multirow[t]{2}{*}{0.547} \\
\hline No & 59 & $49(83.1)$ & $10(16.9)$ & & \\
\hline \multicolumn{6}{|l|}{ TNM stage } \\
\hline । & 29 & $27(93.1)$ & $2(6.9)$ & \multirow[t]{4}{*}{4.40} & 0.121 \\
\hline$\|$ & 37 & $28(75.7)$ & $9(24.3)$ & & \\
\hline III & 16 & $15(93.8)$ & $1(6.2)$ & & \\
\hline IV & 0 & $0(0.0)$ & $0(0.0)$ & & \\
\hline
\end{tabular}

detailed clinicohistopathological findings, eighty-two PSEC patients were finally enrolled in this study, including 57 males with a mean age of $61.8 \pm 8.8$ years and 25 females with a mean age of $64.1 \pm 6.6$ years. All the PESC patients were performed surgical treatment and did not receive any radio- or chemo-therapy before surgery. The clinicopathological characteristics of the 82 patients were summarized in Table 1 . The gross appearance of PESC was classified into three types, i.e., polypoid, ulcerative and infiltrating [7]. Overall survival (OS) time was calculated from the day of esophagectomy to death or to the last follow-up. The median follow-up of the entire cohort was 50.1 months (range, 4.1-123.5 months). The success follow-up rate was $94.2 \%$. Informed consent was obtained from all these patients before taking part in our study. This study was approved by the Ethical Committee of Zhengzhou University (No.16047).

\section{Surgical specimen preparation and immunohistochemistry}

The entire surgical specimen was routinely formalinfixed, paraffin-embedded and H\&E stained for histopathological diagnosis and immunohistochenistry assay. The immunoreactivty for pan-cytokeratins AE1/AE3 
Table 3 The expression of AE1/AE3 protein in different components of PESC

\begin{tabular}{|c|c|c|c|c|c|c|c|}
\hline & Number & $\begin{array}{l}\text { Expression rate of AE1/ } \\
\text { AE3 protein (\%) }\end{array}$ & $\begin{array}{l}\text { Positive in epithelial } \\
\text { component (\%) }\end{array}$ & $\begin{array}{l}\text { Positive in spindle } \\
\text { component (\%) }\end{array}$ & $\begin{array}{l}\text { Positive in both of epithelial and } \\
\text { spindle components (\%) }\end{array}$ & $x^{2}$ & $P$ \\
\hline \multicolumn{8}{|l|}{ Age } \\
\hline $\begin{array}{c}< \\
60 \text { years }\end{array}$ & 26 & 19 (73.1) & 19 (73.1) & $6(23.1)$ & $6(23.1)$ & 0.24 & 0.888 \\
\hline $\begin{array}{c}\geq \\
60 \text { years }\end{array}$ & 56 & 51 (91.1) & $51(91.1)$ & $13(23.2)$ & $13(23.2)$ & & \\
\hline \multicolumn{8}{|l|}{ Gender } \\
\hline Male & 57 & $48(84.2)$ & $48(84.2)$ & $13(22.8)$ & $13(22.8)$ & 0.00 & 1.000 \\
\hline Female & 25 & $22(88.0)$ & $22(88.0)$ & $6(24.0)$ & $6(24.0)$ & & \\
\hline \multicolumn{8}{|c|}{ Family history } \\
\hline Positive & 18 & $16(88.9)$ & $16(88.9)$ & $1(5.6)$ & $1(5.6)$ & 5.777 & 0.118 \\
\hline Negative & 64 & $54(84.3)$ & $54(84.3)$ & $18(28.1)$ & $18(28.1)$ & & \\
\hline \multicolumn{8}{|l|}{ Smoking } \\
\hline Yes & 41 & 34 (82.9) & 34 (82.9) & $10(24.4)$ & $10(24.4)$ & 0.197 & 0.978 \\
\hline No & 41 & $36(87.8)$ & $36(87.8)$ & $9(22.0)$ & $9(22.0)$ & & \\
\hline \multicolumn{8}{|l|}{ Alcohol } \\
\hline Yes & 36 & $30(83.3)$ & $30(83.3)$ & $10(27.8)$ & $10(27.8)$ & 1.154 & 0.764 \\
\hline No & 46 & $40(87.0)$ & $40(87.0)$ & $9(19.6)$ & $9(19.6)$ & & \\
\hline \multicolumn{8}{|c|}{ Tumor location } \\
\hline Upper & 3 & $2(66.7)$ & $2(66.7)$ & $1(33.3)$ & $1(33.3)$ & 6.42 & 0.126 \\
\hline Middle & 54 & $46(85.2)$ & $46(85.2)$ & 16 (29.6) & 16 (29.6) & & \\
\hline Lower & 25 & $22(88.0)$ & $22(88.0)$ & $2(8.0)$ & $2(8.0)$ & & \\
\hline \multicolumn{8}{|c|}{ Gross appearance } \\
\hline Polypoid & 69 & $59(85.5)$ & $59(85.5)$ & $15(21.7)$ & $15(21.7)$ & 3.22 & 0.794 \\
\hline Ulcerative & 8 & $6(75.0)$ & $6(75.0)$ & $1(12.5)$ & $1(12.5)$ & & \\
\hline Infiltrating & 5 & $5(100.0)$ & $5(100.0)$ & $3(60.0)$ & $3(60.0)$ & & \\
\hline \multicolumn{8}{|c|}{ Lymph node metastasis } \\
\hline Yes & 23 & $21(91.3)$ & $21(91.3)$ & $8(34.8)$ & $8(34.8)$ & 1.60 & 0.449 \\
\hline No & 59 & $49(83.1)$ & $49(83.1)$ & $11(18.6)$ & $11(18.6)$ & & \\
\hline \multicolumn{8}{|l|}{ TNM stage } \\
\hline 1 & 29 & $27(93.1)$ & $27(93.1)$ & $3(10.3)$ & $3(10.3)$ & 6.71 & 0.146 \\
\hline$\|$ & 37 & $28(75.7)$ & $28(75.7)$ & $9(24.3)$ & $9(24.3)$ & & \\
\hline III & 16 & $15(93.8)$ & $15(93.8)$ & $7(43.8)$ & $7(43.8)$ & & \\
\hline IV & 0 & $0(0.0)$ & $0(0.0)$ & $0(0.0)$ & $0(0.0)$ & & \\
\hline
\end{tabular}

(AE1/AE3 for short) and CK5/6, chiefly in epithelial component and vimentin, chiefly in spindle component, was determined in this study. The AE3 monoclonal antibody recognizes the 65 to 67 triplet, $64,59,58,56,54$ and $52 \mathrm{kD}$ proteins also known as cytokeratin $1,2,3,4$, $5,6,7$, and 8 while the AE1 antibody recognizes 56.5, $54,50,50,48$, and $40 \mathrm{kDa}$ proteins (also known as CK10, 14, 15, 16 and 19). The AE1/AE3, CK5/6 and vimentin antibodies were all monoclonal mouse antibodies
(1:100 dilutions, Gene Tech, USA). Immunohistochemistry was carried out by a two-step protocol (Benchmark XT, Roche). In brief, the $5 \mu \mathrm{m}$ paraffin-embedded tissue sections were deparaffinized, rehydrated and immersed in $3 \%$ hydrogen peroxide solution for $10 \mathrm{~min}$, heated in citrate buffer $\left(\mathrm{pH}\right.$ 6.0) for $25 \mathrm{~min}$ at $95{ }^{\circ} \mathrm{C}$, and cooled for $60 \mathrm{~min}$ at room temperature. Between each incubation step, the slides were washed with phosphate buffered saline (PBS, $\mathrm{pH}$ 7.4). Immunostaining was performed 
using Roche Benchmark XT with diaminobenzidine (DAB) according to manufacturer recommendations (Gene Tech) and subsequently counterstained with hematoxylin. Slides without the addition of primary antibody served as negative control.

\section{Assessment of immunohistochemical results}

Tissue sections were independently and blindly assessed by three independent histopathologists (XM Li, DY Zhang, and Y Zhang). Discrepancies were resolved by consensus. Positive reactions were defined as those showing brown signals in the cell cytoplasm.

Table 4 The expression rate of CK5/6 protein in PESC

\begin{tabular}{|c|c|c|c|c|c|}
\hline & \multirow[t]{2}{*}{ Number } & \multicolumn{2}{|c|}{$\begin{array}{l}\text { Expression rate of } \\
\text { CK 5/6 protein (\%) }\end{array}$} & \multirow[t]{2}{*}{$x^{2}$} & \multirow[t]{2}{*}{$P$} \\
\hline & & Positive $(n=63)$ & Negative $(n=19)$ & & \\
\hline \multicolumn{6}{|l|}{ Age } \\
\hline$<60$ years & 26 & $15(57.7)$ & $11(42.3)$ & \multirow[t]{2}{*}{7.83} & \multirow[t]{2}{*}{0.005} \\
\hline$\geq 60$ years & 56 & $48(85.7)$ & $8(14.3)$ & & \\
\hline \multicolumn{6}{|l|}{ Gender } \\
\hline Male & 57 & $43(75.4)$ & 14 (24.6) & \multirow[t]{2}{*}{0.20} & \multirow[t]{2}{*}{0.652} \\
\hline Female & 25 & $20(80.0)$ & $5(20.0)$ & & \\
\hline \multicolumn{6}{|l|}{ Family history } \\
\hline Positive & 18 & 15 (83.3) & $3(16.7)$ & \multirow[t]{2}{*}{0.18} & \multirow[t]{2}{*}{0.671} \\
\hline Negative & 64 & $48(75.0)$ & $16(25.0)$ & & \\
\hline \multicolumn{6}{|l|}{ Smoking } \\
\hline Yes & 41 & $30(73.2)$ & $11(26.8)$ & \multirow[t]{2}{*}{0.62} & \multirow[t]{2}{*}{0.432} \\
\hline No & 41 & $33(80.5)$ & $8(19.5)$ & & \\
\hline \multicolumn{6}{|l|}{ Alcohol } \\
\hline Yes & 36 & $26(72.2)$ & $10(27.8)$ & \multirow[t]{2}{*}{0.77} & \multirow[t]{2}{*}{0.382} \\
\hline No & 46 & 37 (80.4) & $9(19.7)$ & & \\
\hline \multicolumn{6}{|c|}{ Tumor location } \\
\hline Upper & 3 & $2(66.7)$ & $1(33.3)$ & \multirow[t]{3}{*}{2.87} & \multirow[t]{3}{*}{0.267} \\
\hline Middle & 54 & $39(72.2)$ & 15 (27.8) & & \\
\hline Lower & 25 & $22(88.0)$ & $3(12.0)$ & & \\
\hline \multicolumn{6}{|c|}{ Gross appearance } \\
\hline Polypoid & 69 & $53(76.8)$ & $16(23.2)$ & \multirow[t]{3}{*}{2.08} & \multirow[t]{3}{*}{0.350} \\
\hline Ulcerative & 8 & $5(62.5)$ & $3(37.5)$ & & \\
\hline Infiltrating & 5 & $5(100.0)$ & $0(0.0)$ & & \\
\hline \multicolumn{6}{|c|}{ Lymph node metastasis } \\
\hline Yes & 23 & 19 (82.6) & $4(17.4)$ & \multirow[t]{2}{*}{0.23} & \multirow[t]{2}{*}{0.629} \\
\hline No & 59 & $44(74.6)$ & $15(25.4)$ & & \\
\hline \multicolumn{6}{|l|}{ TNM stage } \\
\hline I & 29 & $26(89.7)$ & $3(10.3)$ & \multirow[t]{4}{*}{5.63} & 0.056 \\
\hline$\|$ & 37 & $24(64.9)$ & $13(35.1)$ & & \\
\hline III & 16 & $13(81.3)$ & $3(18.7)$ & & \\
\hline IV & 0 & $0(0.0)$ & $0(0.0)$ & & \\
\hline
\end{tabular}

\section{Statistical analysis}

Statistical analysis was performed using SPSS 16.0 software (SPSS Corp, Chicago, IL, USA). Data was represented as the mean \pm standard deviation for continuous variables or number (\%) for categorical data. Spearman's two-sided rank correlation and Fisher's exact test were used to explore the correlation levels between protein expression and clinical characteristics. To estimate the association between eligible variables and survival time, Kaplan-Meier analysis and log-rank tests were used. Univariate and multivariate analyses were based on the cox proportional hazards regression model. Receiver operating characteristic (ROC) curve analysis was used to determine the predictive value of AE1/AE3 and vimentin proteins expression, and the differences in the area under the curve (AUC) were detected by SPSS 16.0. $P$ value less than 0.05 was considered statistically significant.

\section{Results}

AE1/AE3 expression and clinicopathological features

Histologically, PESC involve both epithelial and spindle components (Fig. 1). The positive AE1/AE3 staining was chiefly observed in cytoplasm of epithelial tumor cells (Fig. 2), with a positive detection rate of $85.4 \%$ (70/82). Interestingly, in 19 cases, AE1/AE3 positive staining was also observed in spindle tumor cells (19/82, 23.2\%). However, AE1/AE3 expression was not observed with any significant association with age, gender, family history, smoking, alcohol, tumor location, gross appearance, lymph node metastasis and TNM stage $(P=0.070,0.914$, $0.919,0.755,0.654,0.580,0.660,0.547$, and 0.121 , respectively, Table 2). Similarly, considering the AE1/AE3 expression in different components of PESC separately, AE1/AE3 expression showed no correlation with age, gender, family history, smoking, alcohol, tumor location,

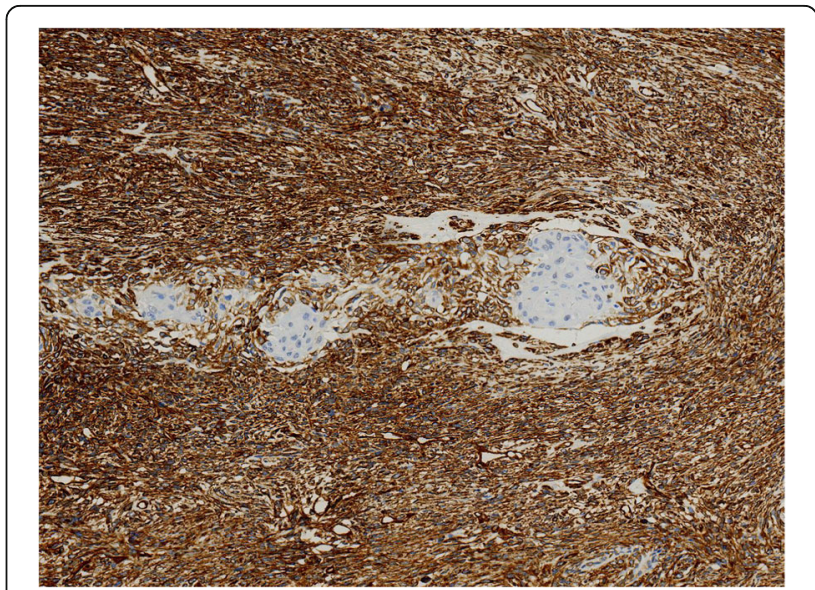

Fig. 3 The protein expressions of vimentin in PESC tissues by immunohistochemistry (100x). The positive immunostaining of vimentin was localized in cell cytoplasm of spindle component 
gross appearance, lymph node metastasis, and TNM stage $(P=0.888,1.000,0.118,0.978,0.764,0.126,0.794$, 0.449 , and 0.146 , respectively, Table 3 ).

\section{CK5/6 expression and clinicopathological features}

The positive CK5/6 staining was chiefly observed in cytoplasm of epithelial tumor cells, with a positive detection rate of $76.8 \%$ (63/82). CK5/6 protein was obviously expressed in age upper 60 years $(P=0.005)$. However, CK5/6 expression was not observed with any significant association with gender, family history, smoking, alcohol, tumor location, gross appearance, lymph node metastasis and TNM stage $(P=0.652,0.671,0.432,0.382,0.267$, $0.350,0.629$, and 0.056 , respectively, Table 4).

\section{Vimentin expression and clinicopathological features}

Vimentin positive expression was chiefly observed in the cytoplasm of spindle tumor cells. In this study, all the 82 patients $(82 / 82,100.0 \%)$ with vimentin were positive staining (Fig. 3). In contrast, only 7 PESC patients showed positive vimentin expression in epithelial tumor components. Moreover, the vimentin expression in different

Table 5 The expression of vimentin protein in different components of PESC

\begin{tabular}{|c|c|c|c|c|c|c|c|}
\hline & Number & $\begin{array}{l}\text { Expression rate of } \\
\text { vimentin protein (\%) }\end{array}$ & $\begin{array}{l}\text { Positive in epithelial } \\
\text { component (\%) }\end{array}$ & $\begin{array}{l}\text { Positive in spindle } \\
\text { component (\%) }\end{array}$ & $\begin{array}{l}\text { Positive in both of epithelial } \\
\text { and spindle components (\%) }\end{array}$ & $x^{2}$ & $P$ \\
\hline \multicolumn{8}{|l|}{ Age } \\
\hline $\begin{array}{c}< \\
60 \text { years }\end{array}$ & 26 & $26(100.0)$ & $2(7.7)$ & $26(100.0)$ & $2(7.7)$ & 0.15 & 1.000 \\
\hline $\begin{array}{c}\geq \\
60 \text { years }\end{array}$ & 56 & $56(100.0)$ & $5(8.9)$ & $56(100.0)$ & $5(8.9)$ & & \\
\hline \multicolumn{8}{|l|}{ Gender } \\
\hline Male & 57 & $57(100.0)$ & $5(8.8)$ & $57(100.0)$ & $5(8.8)$ & 0.15 & 1.000 \\
\hline Female & 25 & $25(100.0)$ & $2(8.0)$ & $25(100.0)$ & $2(8.0)$ & & \\
\hline \multicolumn{8}{|c|}{ Family history } \\
\hline Positive & 18 & $18(100.0)$ & $3(16.7)$ & $18(100.0)$ & $3(16.7)$ & 3.347 & 0.309 \\
\hline Negative & 64 & $64(100.0)$ & $4(6.3)$ & $64(100.0)$ & $4(6.3)$ & & \\
\hline \multicolumn{8}{|l|}{ Smoking } \\
\hline Yes & 41 & $41(100.0)$ & $4(9.8)$ & $41(100.0)$ & $4(9.8)$ & 0.379 & 1.000 \\
\hline No & 41 & $41(100.0)$ & $3(7.3)$ & $41(100.0)$ & $3(7.3)$ & & \\
\hline \multicolumn{8}{|l|}{ Alcohol } \\
\hline Yes & 36 & $36(100.0)$ & $5(13.9)$ & $36(100.0)$ & $5(13.9)$ & 3.782 & 0.282 \\
\hline No & 46 & $46(100.0)$ & $2(4.3)$ & $46(100.0)$ & $2(4.3)$ & & \\
\hline \multicolumn{8}{|c|}{ Tumor location } \\
\hline Upper & 3 & $3(100.0)$ & $0(0.0)$ & $3(100.0)$ & $0(0.0)$ & 1.57 & 0.832 \\
\hline Middle & 54 & $54(100.0)$ & $4(7.4)$ & $54(100.0)$ & $4(7.4)$ & & \\
\hline Lower & 25 & $25(100.0)$ & $3(12.0)$ & $25(100.0)$ & $3(12.0)$ & & \\
\hline \multicolumn{8}{|c|}{ Gross appearance } \\
\hline Polypoid & 69 & $69(100.0)$ & $5(7.2)$ & $69(100.0)$ & $5(7.2)$ & 7.59 & 0.188 \\
\hline Ulcerative & 8 & $8(100.0)$ & $0(0.0)$ & $8(100.0)$ & $0(0.0)$ & & \\
\hline Infiltrating & 5 & $5(100.0)$ & $2(40.0)$ & $5(100.0)$ & $2(40.0)$ & & \\
\hline \multicolumn{8}{|c|}{ Lymph node metastasis } \\
\hline Yes & 23 & $23(100.0)$ & $2(8.7)$ & $23(100.0)$ & $2(8.7)$ & 0.21 & 1.000 \\
\hline No & 59 & $59(100.0)$ & $5(8.5)$ & $59(100.0)$ & $5(8.5)$ & & \\
\hline \multicolumn{8}{|l|}{ TNM stage } \\
\hline I & 29 & $29(100.0)$ & $0(0.0)$ & $29(100.0)$ & $0(0.0)$ & 7.50 & 0.067 \\
\hline$\|$ & 37 & $37(100.0)$ & $5(13.5)$ & $37(100.0)$ & $5(13.5)$ & & \\
\hline III & 16 & $16(100.0)$ & $2(12.5)$ & $16(100.0)$ & $2(12.5)$ & & \\
\hline IV & 0 & $0(0.0)$ & $0(0.0)$ & $0(0.0)$ & $0(0.0)$ & & \\
\hline
\end{tabular}



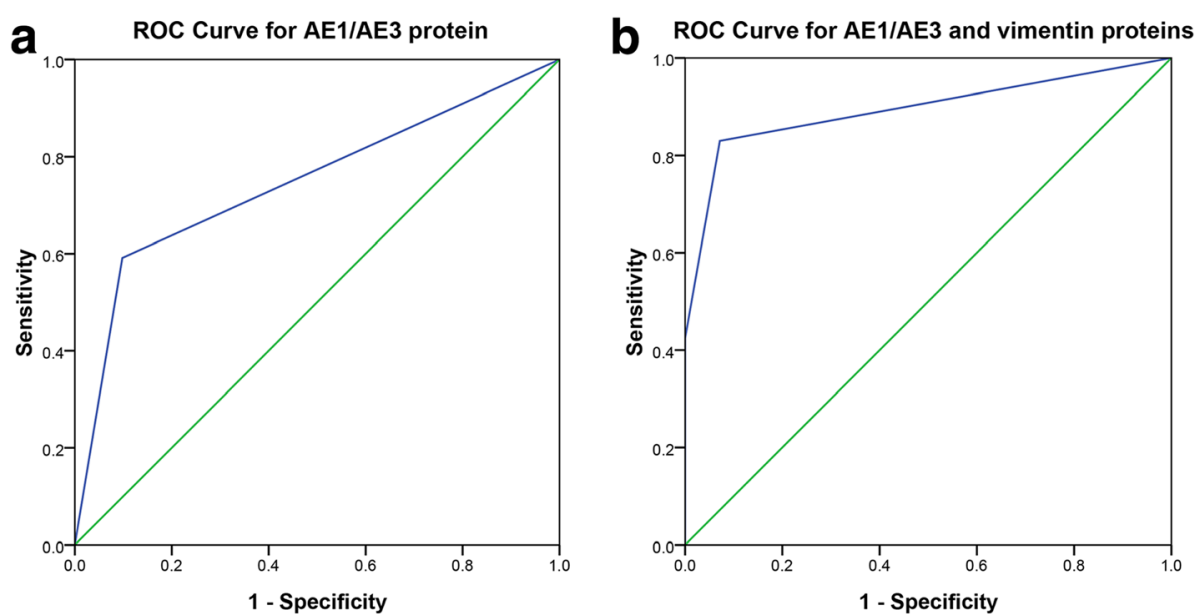

Fig. 4 Predictive ability of diagnostic model. Predictive ability of diagnostic model compared with AE1/AE3 protein shown by receiver operating characteristic (ROC) curves (a) and area under the curve (AUC) in AE1/AE3 and vimentin proteins datasets (b)

components of PESC did not show any correlation with age, gender, family history, smoking, alcohol, tumor location, gross appearance, lymph node metastasis, and TNM stage $(P=1.000,1.000,0.309,1.000,0.282,0.832,0.188,1$. 000 , and 0.067 , respectively, Table 5).

\section{Predictive diagnostic model}

To determine the diagnosis value with these two immunohistocheminal proteins in PESC, the predictive diagnostic model was calculated as $\mathrm{Y}=(\beta 1) \times(\mathrm{AE} 1 / \mathrm{AE} 3)+(\beta 2)$ $x$ (vimentin), with $Y$ equal to risk score and $\beta \mathrm{n}$ equal to each protein's coefficient value from univariate cox proportional hazards regression analysis [8]. The corresponding coefficients were as follows: $\beta 1=0.337$ and $\beta 2=0.519$. Patients were ranked and divided into positive and negative groups using the 50th percentile (i.e., median) risk score as the cut-off value. The area under the receiver operating characteristic (ROC) curve for AE1/AE3 protein was 0.75 (95\% CI $=0.68-0.82)$ (Fig. $4 \mathrm{~A}$ ). In comparison with a single protein, the predictive power of the AE1/AE3 and vimentin proteins signature was increased apparently than with single signature $[0.75(95 \% \mathrm{CI}=0.68-0.82)$ with single protein in Fig. 3 A v.s. 0.89 (95\% CI $=0.85-0.94)$ with $\mathrm{AE} 1 / \mathrm{AE} 3$ and vimentin proteins in Fig. 4 B].

\section{CK protein expression and PESC survival}

The median OS was 34.0 months (range, 2.9-121. 3 months) (Fig. 5). The 1-, 3-, 5- and 7-year survival rates for PESC patients in this study were 79.3\%, 46.3\%, 28.0\% and $15.9 \%$, respectively. Kaplan-Meier analysis showed that age, gross appearance and TNM stage were the important factors to affect survival. The PESC patients with age under 60 years had a better survival than age upper 60 years $(P=0.036$, Fig. 6 A). The survival in the infiltrating gross appearance was of the worst prognosis than other gross appearances $(P=0.001$, Fig. 6 B). The TNM stage used for esophageal squamous cell carcinoma could make a clear different survival curve for stage I, II and III $(P=0.015$, Fig. $6 \mathrm{C})$. Furthermore, multivariate analysis demonstrated that age and TNM stage were independent prognostic factors for overall survival $(\mathrm{P}=0.036$ and 0 . 003, respectively, Table 6). Surprisingly, the univariate analyses showed no difference for survival in the patients with and without lymph node metastasis $(0.51$ ( $95 \% \mathrm{CI}=0.23$ 1.08), $P=0.072$, Fig. $6 \mathrm{D}$ ). And there was no significant difference among lymph node metastasis and 1-,3-, 5-, 7and over 7 -year survival $(P=0.129$, Table 7). Similar results were observed in tumor location $(P=0.109)$, gender

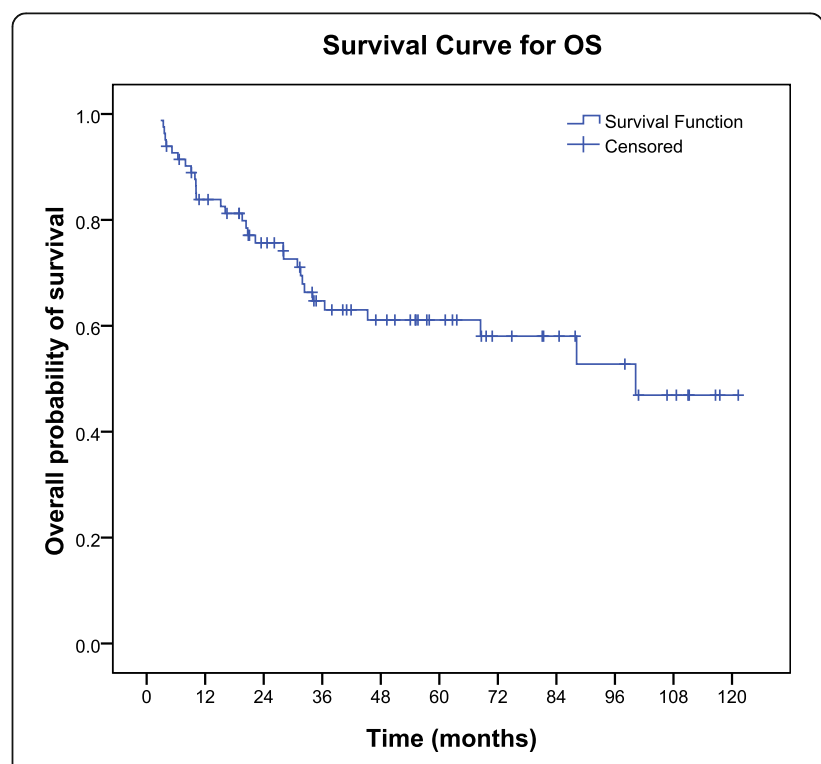

Fig. 5 The curve for the whole cohort overall survival (OS) 

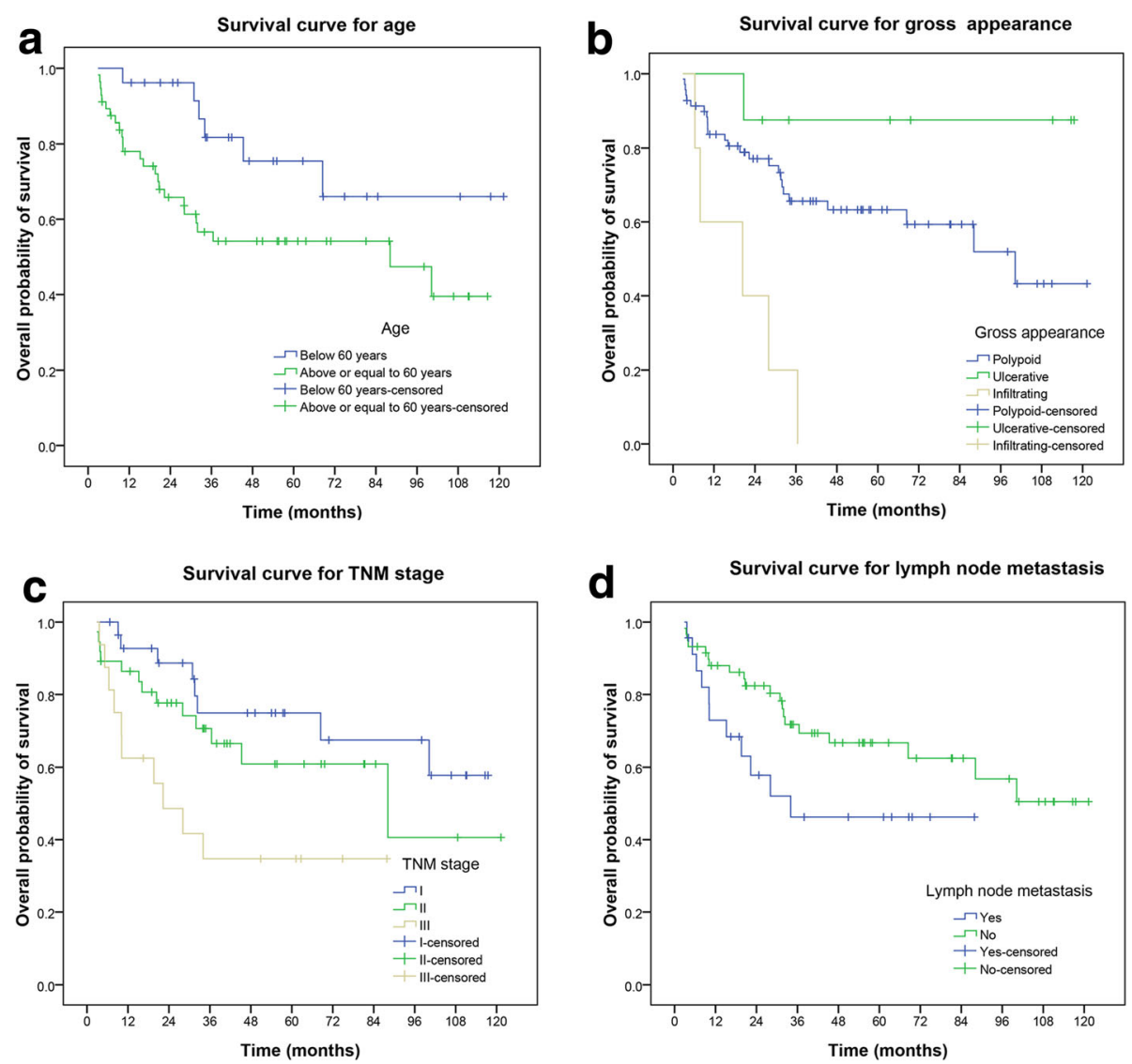

Fig. 6 Kaplan-Meier analysis of overall survival for age $(P=0.036)(\mathbf{a})$, gross appearance $(P=0.001)(\mathbf{b})$, TNM stage $(P=0.015)(\mathbf{c})$ and lymph node metastasis $(P=0.072)(\mathbf{d})$ in the generation dataset of 82 cases

( $P=0.537)$, smoking $(P=0.348)$, alcohol $(P=0.850)$, and family history $(P=0.115)$.

The univariate and multivariate analyses showed that AE1/AE3 and CK5/6 proteins expression were not related with PESC survival (Table 6).

\section{Comparison on PESC diagnosis by biopsy with surgical resection specimen}

In the present study, all the 82 patients were confirmed as PESC by surgical pathology. However, only 14 patients had a PESC diagnosis by biopsy pathology before surgery $(14 / 82,17.1 \%)$. Of the misdiagnosed patients with biopsy pathology, $72.4 \%$ had been diagnosed as squamous cell carcinoma followed by adenocarcinoma and others.

\section{Clinicopathological features with different stage}

In this study, most of PESC symptoms at presentation were dysphagia, $(93.1 \%$ in stage I, $86.5 \%$ in stage II, and $93.8 \%$ in stage III), followed by odynophagia (6.9\% in stage I, $5.4 \%$ in stage II and $6.2 \%$ in stage III), and no difference was observed for the early (stage I) and advanced (stage II and III) in symptom distribution $(P=0.594)$.
Similarly, it did not show any correlation for the staging with age $(P=0.494)$, gender $(P=0.911)$, family history $(P=0.885)$, smoking $(P=0.768)$, alcohol $(P=0$. $242)$, tumor location $(P=0.960)$ and gross appearance $(P=0.221$, Table 8$)$.

\section{Discussion}

As we knew, this is the largest sample size report on cytokeratin and vimentin protein expression and PESC diagnosis and prognosis. The present results demonstrate that cytokertain, expressed chiefly in epithelial tumor cells, and vimentin, expressed always in spindle tumor cells, are useful biomarker in PESC diagnosis, especially, the predictive power of the AE1/AE3 and vimment proteins signature together was increased apparently than with single signature. However, the AE1/ AE3, CK5/6 and vimment proteins expressions did not show any significant effects on PESC survival. Furthermore, no relationship was observed for the AE1/AE3 and vimment proteins expression and age, gender, tumor location, gross appearance, lymph node metastasis, and TNM stage. Similarly, the expression CK5/6 did not show relationship with gender, tumor location, gross 
Table 6 Univariate and multivariate analysis of survival on clinicopathological factors

\begin{tabular}{|c|c|c|c|c|c|c|c|}
\hline & \multirow[t]{2}{*}{ Number } & \multicolumn{3}{|c|}{$\underline{\text { Univariate analysis }}$} & \multicolumn{3}{|c|}{ Multivariate analysis } \\
\hline & & $\mathrm{HR}$ & $95 \% \mathrm{Cl}$ & $P$ & $\mathrm{HR}$ & $95 \% \mathrm{Cl}$ & $P$ \\
\hline \multicolumn{8}{|l|}{ Age } \\
\hline$<60$ years & 26 & 2.52 & $(1.03-6.16)$ & 0.036 & 2.66 & $(1.06-6.63)$ & 0.036 \\
\hline$\geq 60$ years & 56 & & & & & & \\
\hline \multicolumn{8}{|l|}{ Gender } \\
\hline Male & 57 & 0.77 & $(0.34-1.75)$ & 0.537 & & & \\
\hline Female & 25 & & & & & & \\
\hline \multicolumn{8}{|l|}{ Family history } \\
\hline Positive & 18 & 0.40 & $(0.12-1.31)$ & 0.115 & & & \\
\hline Negative & 64 & & & & & & \\
\hline \multicolumn{8}{|l|}{ Smoking } \\
\hline Yes & 41 & 0.71 & $(0.35-1.46)$ & 0.348 & & & \\
\hline No & 41 & & & & & & \\
\hline \multicolumn{8}{|l|}{ Alcohol } \\
\hline Yes & 36 & 1.07 & $(0.53-2.18)$ & 0.850 & & & \\
\hline No & 46 & & & & & & \\
\hline \multicolumn{8}{|c|}{ Tumor location } \\
\hline Upper & 3 & 1.96 & $(0.96-4.01)$ & 0.109 & & & \\
\hline Middle & 54 & & & & & & \\
\hline Lower & 25 & & & & & & \\
\hline \multicolumn{8}{|c|}{ Gross appearance } \\
\hline Polypoid & 69 & 1.58 & $(0.90-2.77)$ & 0.001 & 1.38 & $(0.79-2.39)$ & 0.256 \\
\hline Ulcerative & 8 & & & & & & \\
\hline Infiltrating & 5 & & & & & & \\
\hline \multicolumn{8}{|c|}{ Lymph node metastasis } \\
\hline Yes & 23 & 0.51 & $(0.24-1.08)$ & 0.072 & & & \\
\hline No & 59 & & & & & & \\
\hline \multicolumn{8}{|l|}{ TNM stage } \\
\hline 1 & 29 & 1.95 & $(1.18-3.21)$ & 0.015 & 2.11 & $(1.28-3.50)$ & 0.003 \\
\hline$\|$ & 37 & & & & & & \\
\hline III & 16 & & & & & & \\
\hline IV & 0 & & & & & & \\
\hline \multicolumn{8}{|c|}{ AE1/AE3 protein } \\
\hline Positive & 70 & 1.10 & $(0.83-1.45)$ & 0.527 & & & \\
\hline Negative & 12 & & & & & & \\
\hline \multicolumn{8}{|l|}{ CK5/6 protein } \\
\hline Positive & 63 & 1.82 & $(0.70-4.73)$ & 0.222 & & & \\
\hline Negative & 19 & & & & & & \\
\hline
\end{tabular}

Abbreviations: $\mathrm{Cl}$ confidence interval, $H R$ hazard ratio

appearance, lymph node metastasis, and TNM stage. The major genetic abnormalities for PESC remain largely unknown. Only few series genetic studies have been published with conflicting results regarding the type of alteration present in the two tumor components. The p53 protein over-expression and CD-1 gene amplification seem to occur frequently in both tumor components, in contrast, E-cadherin protein expression is observed chiefly in epithelial component $[9,10]$. However, because of that most genetic studies involve single or small number of cases, the value of the observed genetic changes in PESC prognosis is not clear. 
Table 7 Lymph node metastasis and survival

\begin{tabular}{lllll}
\hline $\begin{array}{l}\text { Survival } \\
\text { (year) }\end{array}$ & \multicolumn{2}{l}{ Lymph node metastasis } & $x^{2}$ & P \\
\cline { 2 - 3 } & Yes $(n=23)$ & No $(n=59)$ & & \\
\hline 1 & $16(69.5)$ & $49(83.1)$ & 6.697 & 0.129 \\
3 & $6(26.1)$ & $30(50.8)$ & & \\
5 & $2(8.7)$ & $17(28.8)$ & & \\
7 & $0(0.0)$ & $12(20.3)$ & & \\
Over 7 & $0(0.0)$ & $10(16.9)$ & & \\
\hline
\end{tabular}

Interestingly, the present study demonstrates that 23 . $2 \%$ of PESC has a positive AE1/AE3 immunoreactivity in both epithelial and spindle tumor components. Similar results are observed in $8.5 \%$ of PESC for vimentin. These findings suggest that PESC may originate from same clone. The histogenesis for PSEC remains inconclusive. Further whole genomic sequencing pattern may shed light on the molecular clue for PESC histogenesis.
The present study demonstrates a slight better 5-year survival for PSEC than esophageal squamous cell carcinoma [11]. The gross appearance and TNM stage are independent prognostic factors for overall survival, and, in this study, the PESC patients with lymph node metastasis did not show worsen prognosis than those without lymph node metastasis. The reason is not clear. Lymph node metastasis has been well documented as risk factor for esophageal squamous cell carcinoma [12-17]. It is noteworthy that the prevalence of lymph node metastasis in PESC is apparently lower than in esophageal squamous cell carcinoma, which may contribute to the better survival for PESC than the esophageal squamous cell carcinoma. Histopathologically, PESC is composed by epithelial and spindle components. In the present study, only 23 PSEC patients occurring lymph node metastasis, almost all the lymph node metastatic components are epithelial. Therefore, it is desirable to characterize the

Table 8 The clinicopathological features with different stage in PESC

\begin{tabular}{|c|c|c|c|c|c|c|}
\hline & \multirow[t]{2}{*}{ Number } & \multicolumn{3}{|l|}{ Stage (\%) } & \multirow[t]{2}{*}{$x^{2}$} & \multirow[t]{2}{*}{$P$} \\
\hline & & $I(n=29)$ & $\|(n=37)$ & $\| I(n=16)$ & & \\
\hline \multicolumn{7}{|l|}{ Age } \\
\hline$<60$ years & 26 & $7(26.9)$ & $14(53.8)$ & $5(19.3)$ & \multirow[t]{2}{*}{1.41} & \multirow[t]{2}{*}{0.494} \\
\hline$\geq 60$ years & 56 & $22(39.3)$ & $23(41.1)$ & $11(19.6)$ & & \\
\hline \multicolumn{7}{|l|}{ Gender } \\
\hline Male & 57 & 21 (36.8) & $25(43.9)$ & $11(19.3)$ & \multirow[t]{2}{*}{0.19} & \multirow[t]{2}{*}{0.911} \\
\hline Female & 25 & $8(32.0)$ & $12(48.0)$ & $5(20.0)$ & & \\
\hline \multicolumn{7}{|l|}{ Family history } \\
\hline Positive & 18 & $6(33.3)$ & $9(50.0)$ & $3(16.7)$ & \multirow[t]{2}{*}{0.25} & \multirow[t]{2}{*}{0.885} \\
\hline Negative & 64 & $23(35.9)$ & $28(43.8)$ & $13(20.3)$ & & \\
\hline \multicolumn{7}{|l|}{ Smoking } \\
\hline Yes & 41 & 15 (36.6) & $17(41.5)$ & $9(21.9)$ & \multirow[t]{2}{*}{0.53} & \multirow[t]{2}{*}{0.768} \\
\hline No & 41 & $14(34.1)$ & $20(48.8)$ & $7(17.1)$ & & \\
\hline \multicolumn{7}{|l|}{ Alcohol } \\
\hline Yes & 36 & 11 (30.6) & $15(41.7)$ & $10(27.7)$ & \multirow[t]{2}{*}{2.84} & \multirow[t]{2}{*}{0.242} \\
\hline No & 46 & 18 (39.1) & $22(47.8)$ & $6(13.1)$ & & \\
\hline \multicolumn{7}{|l|}{ Tumor location } \\
\hline Upper & 3 & $1(33.3)$ & $2(66.7)$ & $0(0.0)$ & \multirow[t]{3}{*}{1.17} & \multirow[t]{3}{*}{0.960} \\
\hline Middle & 54 & 19 (35.2) & $23(42.6)$ & $12(22.2)$ & & \\
\hline Lower & 25 & $9(36.0)$ & $12(48.0)$ & $4(16.0)$ & & \\
\hline \multicolumn{7}{|c|}{ Gross appearance } \\
\hline Polypoid & 69 & $25(36.2)$ & $30(43.5)$ & $14(20.3)$ & \multirow[t]{3}{*}{5.21} & \multirow[t]{3}{*}{0.221} \\
\hline Ulcerative & 8 & $4(50.0)$ & $4(50.0)$ & $0(0.0)$ & & \\
\hline Infiltrating & 5 & $0(0.0)$ & $3(60.0)$ & $2(40.0)$ & & \\
\hline \multicolumn{7}{|c|}{ Lymph node metastasis } \\
\hline Yes & 23 & $1(4.3)$ & $7(30.4)$ & $15(65.3)$ & \multirow[t]{2}{*}{42.27} & \multirow[t]{2}{*}{0.000} \\
\hline No & 59 & $28(47.5)$ & $30(50.8)$ & $1(1.7)$ & & \\
\hline
\end{tabular}


PESC lymph node metastasis by different components to correlate with survival in large cohort study.

It is noteworthy that the biopsy accurate diagnosis for PESC before radical esophagectomy is much lower than the surgical diagnosis. $72 \%$ of PESC had been diagnosed as squamous cell carcinoma. Obviously, the too small size is the major reason for this poor biopsy accurate diagnosis. Another reason is because of the predominant epithelial component in these PESC patients. Fortunately, this partial diagnosis has no impact on therapy for the moment [9].

\section{Conclusions}

In summary, the present study demonstrates that cytokeratin and vimentin protein immunoassay is a useful biomarker for PESC accurate diagnosis, but not prognosis. The co-expression of cytokeratin and vimentin in both epithelial and spindle components suggest the possibility of single clone origination for PESC. PESC occurs predominantly in male patient (male:female, 2.3:1) with a peak age of 60 years old. PESC are located more frequently in the middle segment. The age and TNM stage of PESC are independent prognostic factors.

\section{Abbreviations}

AUC: Area under the curve; Cl: Confidence interval; CK: Cytokeratin; DAB: Diaminobenzidine; HR: Hazard ratio; PESC: Primary esophageal spindle cell carcinoma; ROC: Receiver operating characteristic

\section{Acknowledgements}

We thank all the patients and their family members whose contributions made this work possible. We thank $P$ Zhang and XC Jia for their help in survival statistics.

\section{Funding}

This work was supported by the National High-Tech Research and Development Program of China (SQ2015AA0202183 to LD Wang), and the National Natural Science Foundation of China (U1301227 to LD Wang). The funding body had no role in the design of the study and collection, analysis, and interpretation of data and in writing the manuscript.

\section{Availability of data and materials}

The datasets generated during and analysed during the current study are available from the corresponding author on reasonable request.

\section{Authors' contributions}

LDW organized and designed the study. XS, XKZ and ZMF conducted and supervised the samples of PESC. XML, YZ and LDW contributed to the design and execution of statistical analysis. XML and LDW wrote the first draft of the manuscript. SJH, RC, SL, DFD, XYZ, JLL, JWK and DYZ contributed to the conduct of the epidemiological studies or PESC immunohistochenistry assay or follow-up. XML, DYZ and YZ contributed to the assession of tissue sections. XML and LDW contributed to the writing and revising of the manuscript. All authors read and approved the final manuscript.

\section{Ethics approval and consent to participate}

Since the tissues used in this study are from patients diagnosed between 1973 and 2015 not from all patients a written informed consent is available. But in accordance with the Chinese law, the study was reviewed and approved by the Ethics committee of Zhengzhou University (No.16047) and it was conducted in accordance with the Declaration of Helsinki. All samples were anonymized before analysis was performed, to guarantee the protection of privacy.
Consent for publication

Not applicable.

\section{Competing interests}

The authors declare that they have no competing interests.

\section{Publisher's Note}

Springer Nature remains neutral with regard to jurisdictional claims in published maps and institutional affiliations.

\section{Author details}

${ }^{1}$ Henan Key Laboratory for Esophageal Cancer Research of the First Affiliated Hospital, Zhengzhou University, 40 Daxue Road, Zhengzhou, Henan 450052, People's Republic of China. ${ }^{2}$ Department of Pathology, Xinxiang Medical University, Xinxiang 453003, Henan, China. ${ }^{3}$ Department of Pathology of Basic Medical College, Zhengzhou University, Zhengzhou 450001, Henan, China. ${ }^{4}$ Department of Gastroenterology, the Second Affiliated Hospital of Nanyang Medical College, Nanyang 473061, Henan, China. ${ }^{5}$ Department of Pathology of Nanyang Medical College, Nanyang 473061, Henan, China. ${ }^{6}$ Department of Pathology, Women \& Infants Hospital of Zhengzhou, Zhengzhou 450012, Henan, China.

Received: 31 October 2016 Accepted: 23 March 2018

Published online: 02 April 2018

\section{References}

1. Bosman FT, Catneiro F, Hruban RH, Theise ND. WHO Classiffical of tumor of the digestive system. In: Bosman FT, Catneiro F, Hruban RH, Theise ND, editors. The International Agency for Research on Cancer. Lyon; 2010. p. 20-2.

2. Cha RR, Jung WT, Oh HW, Kim HJ, Ha CY, Kim HJ, Kim TH, Ko GH. A case of metachronous development of esophageal squamous cell carcinoma in the patient with esophageal carcinosarcoma. Korean J Gastroenterol. 2014;64:364-9.

3. Ogasawara N, Tamura Y, Funaki Y, Yamaguchi Y, Shimozato A, Yanamoto K, Takahashi E, Miyachi M, Sasaki M, Kasugai K. Rapidly growing esophageal carcinosarcoma reduced by neoadjuvant radiotherapy alone. Case Rep Gastroenterol. 2014:8:227-34.

4. Raza MA, Mazzara PF. Sarcomatoid carcinoma of esophagus. Arch Pathol Lab Med. 2011;135:945-8.

5. Gaur DS, Kishore S, Saini S, Pathak VP. Carcinosarcoma of the oesophagus. Singap Med J. 2008:49:e283-5.

6. Ji LF, Fan ZM, Wu MJ, Wang R, Kong GQ, Meng H, Zhou YF, Liu TJ, Liu ZC, Fu WT, Wu Y, Cheng R, Wang LD. Clinicpathopathologic features and survival impact factors of 286 patients with esophagus spindle cell carcinoma. J. Zhejiang Univ. (Med. Sci.). 2016;51:565-8.

7. Bosman FT, Catneiro F, Hruban $\mathrm{RH}$, Theise ND. WHO Classiffical of tumor of the digestive system. In: Bosman FT, Catneiro F, Hruban RH, Theise ND, editors. The International Agency for Research on Cancer. Lyon; 2010. p. 16.

8. Sun LL, Wu JY, Wu ZY, Shen JH, Xu XE, Chen B, Wang SH, Li EM, Xu LY. A three-gene signature and clinical outcome in esophageal squamous cell carcinoma. Int J Cancer. 2015;136:E569-77.

9. Amatya VJ, Takeshima Y, Kaneko M, Inai K. Esophageal carcinosarcoma with basaloid squamous carcinoma and rhabdomyosarcoma components with TP53 mutation. Pathol Int. 2004;54:803-9.

10. Suzuki H, Fujioka Y, Nagashima K. Cyclin D1 gene amplification and p16 gene deletion in patients with esophageal carcinosarcoma. Diagn Mol Pathol. 1998:7:253-9.

11. Zeng H, Zheng R, Guo Y, Zhang S, Zou X, Wang N, Zhang L, Tang J, Chen J, Wei K, Huang S, Wang J, Yu L, Zhao D, Song G, Chen J, Shen Y, Yang X, Gu X Jin F, Li Q, Li Y, Ge H, Zhu F, Dong J, Guo G, Wu M, Du L, Sun X, He Y, Coleman MP, Baade P, Chen W, Yu XQ. Cancer survival in China, 2003-2005: a population-based study. Int J Cancer. 2015;136:1921-30.

12. Jaffer AA, Thomas AD, Khaldoun A, David JB, Stephen B, Joseph C, Prajnan D, Crystal D, Paul F, Charles SF, Hans G, Robert EG, James AH, Steven H, Wayne LH, David HI, Dawn J, Kory J, Rajesh NK, Lawrence RK, W Michael K, Stephen L, A Craig L, Mary FM, Mark BO, James AP, George AP, Aaron RS, Walter JS, Vivian ES, Thomas KV, Mary KW, Christopher GW, Cameron DW, Debra Z, Nicole M, Hema S. Esophageal and Esophagogastric Junction Cancers. Version 3. 2015; http://www.nccn.org/patients.

13. Li M, Zeng XO, Tan $L$, Survival CSY. Prognostic evaluation of superficial esophageal cancer after surgery. Zhonghua Yi Xue Za Zhi. 2016;96:460-3. 
14. Gao S, Li S, Ma Z, Liang S, Shan T, Zhang M, Zhu X, Zhang P, Liu G, Zhou F, Yuan X, Jia R, Potempa J, Scott DA, Lamont RJ, Wang H, Feng X. Presence of Porphyromonas gingivalis in esophagus and its association with the clinicopathological characteristics and survival in patients with esophageal cancer. Infect Agent Cancer. 2016;11:3.

15. Hirahara N, Matsubara T, Hayashi H, Takai K, Fujii Y, Tajima Y. Impact of inflammation-based prognostic score on survival after curative thoracoscopic esophagectomy for esophageal cancer. Eur J Surg Oncol. 2015;41:1308-15.

16. Xu XL, Zheng WH, Zhu SM, Zhao A, Mao WM. The prognostic impact of lymph node involvement in large scale operable node-PositiveEsophageal squamous cell carcinoma patients: a 10-year experience. PLoS One. 2015;10: e0133076.

17. Rice TW. Esophageal Cancer staging. Korean J Thorac Cardiovasc Surg. 2015; 48:157-63.

Submit your next manuscript to BioMed Central and we will help you at every step:

- We accept pre-submission inquiries

- Our selector tool helps you to find the most relevant journal

- We provide round the clock customer support

- Convenient online submission

- Thorough peer review

- Inclusion in PubMed and all major indexing services

- Maximum visibility for your research

Submit your manuscript at www.biomedcentral.com/submit
Biomed Central 